Jurnal Indonesia Sosial Teknologi: p-ISSN: 2723 - 6609

e-ISSN : 2745-5254

Vol. 2, No. 10 Oktober 2021

\title{
STUDI ANALISIS HUKUM KEWENANGAN DAN TUGAS KOMISI PEMBERANTASAN KORUPSI DALAM MENCEGAH TINDAK PIDANA KORUPSI BERDASARKAN KETENTUAN UNDANG-UNDANG NOMOR 19 TAHUN 2019
}

\section{Dony Endrassanto}

Program Magister Ilmu Hukum Sekolah Tinggi Ilmu Hukum IBLAM, Jakarta, Indonesia

Email: dony@gmail.com

\section{Abstrak}

Korupsi yang dikategorikan sebagai kejahatan yang luar biasa (extra ordinary crimes) memerlukan upaya pemberantasan dengan cara-cara yang luar biasa (extra ordinary measure). KPK mempunyai tugas, wewenang, dan kewajiban dalam hal penanganan tindak pidana korupsitelah diatur sedemikian rupa dalam UU KPK, ini artinya bahwa dalam penegakan hukum pidana khususnya tindak pidana korupsi, KPK dapat diartikan sebagai lembaga penegak hukum khusus sehingga upayaupaya yang hendak dicapai dalam hal pemberantasan (baik dalam pencegahan maupun penindakan) tindak pidana korupsi di Indonesia dapat lebih maksimal. Rumusan masalah yang penulis bahas dalam tesis ini adalah : 1) Bagaimana Analisis Hukum Komisi Pemberantasan Korupsi menjalankan tugas dalam mencegah terjadinya tindak pidana korupsi?, 2) Bagaimana strategi Hukum Komisi Pemberantasan Korupsi dalam mencegah terjadinya tindak pidana korupsi?. Metode penelitian yang penulis lakukan bersifat deskriptif dengan menggunakan metode yuridis normatif, yaitu memberikan gambaran tentang kinerja Komisi Pemberantasan Korupsi menjalankan tugas dan fungsinya untuk menceglisis Hukum Strategi Komisi Pemberantasan Korupsi dalam mecegah terjadinya tindak pidana korupsi, berdasarkan peraturan perundang-undangan. Data yang diperoleh melalui studi kepustakaan atau data sekunder, terdiri dari bahan hukum primer berupa peraturan perundang-undangan yang relevan dengan penelitian tesis, utamanya yang mengatur tentang kinerja Komisi Pemberantasan Korupsi menjalankan tugas dan fungsinya untuk mencegah tindak pidana korupsi, dan peraturan perundang-undangan lainnya yang berkaitan dengan masalah tersebut. Akhirnya penulis berkesimpulan wewenang KPK yang lebih menonjol di bidang penindakan dibanding pencegahan. Hal itu juga diakui oleh pihak KPK, salah satunya karena yang mencuat ke media lebih banyak upaya-upaya KPK di bidang penindakan. KPK dalam mencegah korupsi berdasarkan analisa hukum dialkukan melalui beberapa strategi yaitu Strategi Pendekatan politik hukum, penegakkan hukum dan budaya hukum serta bekerja sama dengan Kemendikbud, oleh karena itu setidaknya melalui pendidikan anti korupsi mutlak harus masuk dalam kurikulum pendidikan di tiap-tiap strata yang pengembangannya melalui modulmodul untuk pendidik dan tenaga kependidikan agar menjadikan sekolah / perguruan tinggi sebagai tempat menumbuhkan karakter integritas 
Arief Rahman, Warto Utomo, Bangbang Panca Kusuma, Muhammad Thariq Almuqtadir

Kata kunci: Analisis; Korupsi; Tindak Pidana.

\section{Abstract}

Corruption which is categorized as an extraordinary crime (extraordinary crimes) requires eradication efforts in extraordinary ways (extraordinary measure). The KPK has duties, authorities, and obligations in terms of handling corruption crimes which have been regulated in such a way in the KPK Law, this means that in the enforcement of criminal law, especially corruption, the KPK can be interpreted as a special law enforcement agency so that the efforts to be achieved in terms of eradication (both in prevention and prosecution) of corruption in Indonesia can be maximized. The formulation of the problem that the author discusses in this thesis are: 1) How does the Legal Analysis of the Corruption Eradication Commission carry out its duties in preventing corruption?, 2) What is the legal strategy of the Corruption Eradication Commission in preventing corruption? The research method that the author does is descriptive using a normative juridical method, which provides an overview of the performance of the Corruption Eradication Commission in carrying out its duties and functions to check the Legal Strategy of the Corruption Eradication Commission in preventing the occurrence of criminal acts of corruption, based on statutory regulations. Data obtained through literature study or secondary data, consisting of primary legal materials in the form of laws and regulations relevant to the thesis research, especially those that regulate the performance of the Corruption Eradication Commission in carrying out its duties and functions to prevent corruption, and other laws and regulations. related to the problem. Finally, the author concludes that the authority of the KPK is more prominent in the field of prosecution than prevention. This was also acknowledged by the KPK, one of which was because what was sticking out to the media was more of the KPK's efforts in the field of prosecution. The KPK in preventing corruption based on legal analysis is carried out through several strategies, namely the Legal Politics Approach Strategy, law enforcement and legal culture as well as cooperating with the Ministry of Education and Culture, therefore at least through anti-corruption education it is absolutely necessary to include it in the education curriculum in each strata whose development is through modules for educators and education staff to make schools/colleges a place to grow the character of integrity

Keywords: Analysis; Corruption; Criminal act.

\section{Pendahuluan}

Menurut bahasa, "korupsi berasal dari bahasa latin corruptio atau corruptus, dan bahasa latin yang lebih tua dipakai istilah corrumpere. Dari bahasa latin itulah turun ke berbagai bahasa bangsa-bangsa di Eropa. Seperti Inggris : corruption, corrupt, Prancis: corruption; dan Belanda : corruptive atau korruptie, yang kemudian turun ke dalam bahasa Indonesia menjadi korupsi". Arti kata itu ialah kebusukan, keburukan, kebejatan, ketidakjujuran, dapat disuap, tidak bermoral, penyimpangan dari kesucian ( 1991).

Pengertian lain dalam Kamus Besar Bahasa Indonesia, korupsi adalah :

1) Penyelewengan atau penggelapan (uang Negara atau perusahaan dsb) untuk kepentingan pribadi atau orang lain. 
Studi Analisis Hukum Kewenangan dan Tugas Komisi Pemberantasan Korupsi dalam Mencegah Tindak Pidana Korupsi Berdasarkan Ketentuan Undang-Undang Nomor 19

Tahun 2019

2) Menyelewengkan, menggelapkan (uang dsb).

Akan tetapi menurut Pasal 435 KUHP, korupsi berarti busuk, buruk, bejat dan dapat disogok, suka disuap, pokoknya merupakan perbuatan yang buruk. Perbuatan korupsi dalam istilah kriminologi digolongkan kedalam White Collar Crime. Berdasarkan pengertian- pengertian tersebut, definisi korupsi dapat dipandang dari berbagai aspek, bergantung pada disiplin ilmu yang dipergunakan (Suyatno, 2005).

Di dalam penegakan hukum yang dilakukan secara konvensional untuk memberantas tindak pidana korupsi terbukti mengalami berbagai hambatan. Untuk itu diperlukan metode penegakan hukum yang luar biasa melalui pembentukan suatu badan khusus yang mempunyai kewenangan luas, independen, serta bebas dari kekuasaan manapun dalam upaya pemberantasan tindak pidana korupsi, yang pelaksanaanya dilakukan dalam upaya tindak pidana korupsi, yang pelaksanaanya dilakukan secara optimal, intensif, efektif profesional, serta berkesinambungan. Perkembangan tindak pidana korupsi baik dilihat dari sisi kuantitas maupun sisi kualitas dewasa iní dapat dikatakan bahwa korupsi di Indonesia tidak lagi merupakan kejahatan biasa (ordinary crimes), akan tetapi sudah merupakan kejahatan luar biasa (extra ordinary crimes) (Jaya \& Serikat, 2008).

Mengingat kompleksitas serta efek negatifnya, maka korupsi yang dikategorikan sebagai kejahatan yang luar biasa (extra ordinary crimes) memerlukan upaya pemberantasan dengan cara-cara yang luar biasa (extra ordinary measure). Disamping tindak pidana korupsi sering disebut extra ordinary crime, sering kali tindak pidana korupsi ini diidentikkan dengan white collar crime yaitu suatu perbuatan (tidak berbuat) dalam sekelompok kejahatan yang spesifik yang bertentangan dengan hukum pidana yang dilakukan oleh pihak professional, baik oleh individu, organisasi, atau sindikat kejahatan, ataupun dilakukan oleh badan hukum. Menurut Dony Kleden Rohaniwan, kejahatan kerah putih (white collar crime) adalah istilah temuan Hazel Croal untuk menyebut berbagai tindak kejahatan di lembaga pemerintahan yang terjadi, baik secara struktural yang melibatkan sekelompok orang maupun secara individu. Hazel Croal mendifinisikan kejahatan kerah putih sebagai penyalahgunaan jabatan yang sebagaimana ditetapkan oleh hukum. Umumnya, skandal kejahatan kerah putih sulit dilacak karena dilakukan pejabat yang punya kuasa untuk memproduksi hukum dan membuat berbagai keputusan vital.

Sebagaimana diamanatkan dalam Pasal 43 Undang-Undang No. 31 Tahun 1999 tentang Pemberantasan Tindak Pidana Korupsi, sebagaimana diubah dengan UndangUndang No. 20 Tahun 2001 tentang Perubahan atas Undang-Undang No. 31 Tahun 1999 tentang Pemberantasan Tindak Pidana Korupsi (selanjutnya disebut UU Tipikor), bahwa Komisi Pemberantasan Korupsi (selanjutnya disebut KPK) dibentuk dalam jangka waktu selambat-lambatnya 2 (dua) tahun semenjak Undang-Undang tersebut mulai berlaku, yang kemudian diwujudkan dengan Undang-Undang No. 30 Tahun 2002 .

Tentang Komisi Pemberantasan Tindak Pidana Korupsi (selanjutnya disebut UU KPK) dan dipertegas dalam pasal 2 yang berbunyi : "Dengan Undang-Undang ini 
Arief Rahman, Warto Utomo, Bangbang Panca Kusuma, Muhammad Thariq Almuqtadir

dibentuk Komisi Pemberantasan Tindak Pidana Korupsi yang untuk selanjutnya disebut Komisi Pemberantasan Korupsi." Hal ini sesuai dengan ketentuan TAP MPR No. XI/MPR/1998 tentang Penyelenggara Negara yang Bersih dan Bebas Korupsi, Kolusi, dan Nepotisme, artinya Undang-Undang tersebut menjadi dasar hukum yang menjamin sahnya lembaga tersebut dan memuat tugas serta tanggung jawab dari KPK. KPK merupakan lembaga baru dalam konstitusional Indonesia yang eksistensinya masih bersifat relatif dikalangan warga masyarakat maupun Lembaga Negara yang sudah ada sebelumnya. Walaupun KPK bukan merupakan sebuah lembaga penegak hukum inti dalam Sisitem Peradilan Pidana Terpadu di Indonesia, tetapi tugas dan wewenang yang dimiliki dan tanggung jawab yang harus diemban adalah merupakan bagian dari penegakan hukum di Indonesia, khususnya pencegahan dan penindakan tindak pidana korupsi. KPK mempunyai tugas, kewenangan, dan kewajiban dalam hal penanganan tindak pidana korupsi telah diatur sedemikian rupa dalam UU KPK, ini artinya bahwa dalam penegakan hukum pidana khususnya tindak pidana korupsi, KPK dapat diartikan sebagai lembaga penegak hukum khusus sehingga upaya-upaya yang hendak dicapai dalam hal pemberantasan (baik dengan pencegahan maupun penindakan) tindak pidana korupsi di Indonesia dapat lebih maksimal. Selain itu dibentuknya KPK juga dilatarbelakangi alasan karena lembaga pemerintah yang menangani tindak pidana korupsi belum berfungsi secara efisien dan efektif dalam memberantas tindak pidana korupsi (Lilik, 2007).

KPK merupakan suatu komisi organik, yaitu komisi yang lahir dari UndangUndang yakni selanjutnya disebut UU KPK. Pengertian KPK yang tertuang dalam Pasal 3 UU KPK berbunyi : "Komisi Pemberantasan Korupsi adalah lembaga negara yang dalam melaksanakan tugas dan wewenangnya bersifat independen dan bebas dari pengaruh kekuasaan manapun." Dilihat dari pembentukan dan kewenangannya, KPK mempunyai tugas-tugas sebagaimana diatur dalam Pasal 6 UU KPK (Djaja, 2009). Kewenangan KPK yang tertuang dalam Pasal 6 UU KPK, bertugas untuk melakukan penyelidikan, penyidikan, dan penuntutan terhadap tindak pidana korupsi. Dalam ketentuan KUHAP, yaitu dalam Pasal 1 angka (2) menyebutkan yang dimaksud dengan: "Penyidikan adalah serangkain tindakan dalam penyidikan dalam hal dan menurut cara yang diatur dalam undang-undang ini untuk mencari serta mengumpulkan bukti yang dengan bukti itu membuat terang tentang tindak pidana yang terjadi dan guna menemukan tersangkanya.

Banyak dari kalangan masyarakat ataupun kelompok masyarakat yang masih belum memahami dan mengetahui tentang tugas dan serta kewajiban dan independensi KPK dalam memberantas tindak pidana korupsi, sehingga masih banyak yang beranggapan bahwa dalam melakukan pemberantasan tindak pidana korupsi masih bersikap tebang pilih. Berdasarkan ketentuan Pasal 43 Undang-Undang No.31 Tahun 1999 tentang Pemberantasan Tindak Pidana Korupsi, sebagaimana telah diubah dengan Undang-Undang Nomor 20 Tahun 2001, dan diubah dengan Undang-Undang Nomor 19 Tahun 2019, badan khusus tersebut selanjutnya disebut Komisi Pemberantasan Korupsi, memiliki kewenangan melakukan koordinasi dan supervisi, termasuk melakukan 
Studi Analisis Hukum Kewenangan dan Tugas Komisi Pemberantasan Korupsi dalam

Mencegah Tindak Pidana Korupsi Berdasarkan Ketentuan Undang-Undang Nomor 19

Tahun 2019

penyelidikan, penyidikan, dan penuntutan. Sedangkan mengenai pembentukan, susunan organisasi, tata kerja dan pertanggungjawaban, tugas dan wewenang serta keanggotaan diatur dalam Undang-Undang.

Adapun Tugas dan wewenang KPK terdapat dalam Bab II UU No. 30 Tahun 2002 tentang Komisi Pemberantasan Korupsi yang telah diubah ke dalam UU No. 19 Tahun 2019 tentang Perubahan Kedua Atas UU No. 30 Tahun 2002 tentang Komisi Pemberantasan Tindak Pidana Korupsi mencakup wilayah yang sangat luas. Menurut ketentuan Pasal 6 UU No. 19 Tahun 2019 tentang Komisi Pemberantasan Korupsi tersebut, KPK mempunyai tugas-tugas untuk melakukan :

a. Tindakan-tindakan pencegahan sehingga tidak terjadi Tindak Pidana Korupsi;

b. Koordinasi dengan instansi yang berwenang melaksanakan Pemberantasan Tindak Pidana Korupsi dan instansi yang bertugas melaksanakan pelayanan publik;

c. Monitor terhadap penyelenggaraan pemerintahan negara;

d. Supervisi terhadap instansi yang berwenang melaksanakan Pemberantasan Tindak Pidana Korupsi;

e. Penyelidikan, penyidikan, dan penuntutan terhadap Tindak Pidana Korupsi; dan

f. Tindakan untuk melaksanakan penetapan hakim dan putusan pengadilan yang telah memperoleh kekuatan hukum tetap (Pasal 6 UU No. 19 Tahun 2019 tentang Komisi Pemberantasan Korupsi)

Dalam penulisan tesis ini lebih mengkhususkan mengenai kewenangan KPK dalam pencegahan tindak pidana korupsi, yang selama ini penanganan tindak korupsi yang dilakukan oleh Polri banyak menemui hambatan dengan alasan :

1. Laporan masyarakat mengenai tindak pidana korupsi tidak dilanjuti;

2. Proses penanganan tindak pidana korupsi secara berlarut-larut atau tertundatunda tanpa alasan yang dapat dipertanggungjawabkan;

3. Penanganan tindak pidana korupsi ditujukan untuk melindungi pelaku tindak pidana korupsi yang sesungguhnya;

4. Penanganan tindak pidana korupsi mengandung unsur korupsi;

5. Hambatan penangan tindak pidana korupsi karena campur tangan dari eksekutif, yudikatif, atau legislatif; atau

6. Keadaan lain yang menurut pertimbangan kepolisian atau kejaksaan, penanganan tindak pidana korupsi sulit dilaksanakan secara baik dan dapat dipertanggungjawabkan.

Untuk mengetahui dan menganalisa mengenai Analisis Hukum Komisi

Pemberantasan Korupsi menjalankan tugas dalam mencegah terjadinya tindak pidana korupsi. Untuk mengetahui dan menganalisa strategi Hukum Komisi Pemberantasan Korupsi dalam mencegah terjadinya tindak pidana korupsi.

\section{Metode Penelitian}


Arief Rahman, Warto Utomo, Bangbang Panca Kusuma, Muhammad Thariq Almuqtadir

\section{Jenis peneitian}

Penelitian ini bersifat deskriptif dengan menggunakan metode yuridis normatif, yaitu memberikan gambaran tentang kinerja Komisi Pemberantasan Korupsi menjalankan tugas dan fugsinya untuk mencegah terjadinya tindak korupsi dan pola dan strategi Komisi Pemberantasan Korupsi dalam mencegah terjadinya tindak pidana korupsi, berdasarkan peraturan perundang-undangan

\section{Sumber Data}

Data yang diperoleh melalui studi kepustakaan atau data sekunder, terdiri :

a. Bahan hukum primer berupa peraturan perundang-undangan yang relevan dengan penilitian tesis, utamanya yang mengatur tentang kinerja Komisi Pemberantasan Korupsi menjalankan tugas dan fugsinya untuk mencegah terjadinya tindak korupsi dan pola dan strategi Komisi Pemberantasan Korupsi dalam mencegah terjadinya tindak pidana korupsi, dan peraturan perundang-undangan lainnya yang berkaitan dengan masalah.

b. Bahan hukum sekunder ialah literatur-literatur ilmu hukum serta karya ilmiah lainnya yang relevan dengan masalah penelitian.

c. Bahan hukum tertier adalah kamus hukum, kamus bahasa, dan naskah tertulis lainnya yang dapat memperjelas, melengkapi, dan menopang, bahan hukum primer dan sekunder.

\section{Pengumpulan Data}

Dalam perolehan data menggunakan studi kepustakaan dengan cara menginventarisasi, menelusuri, mempelajari dan mencatat peraturan perundang-undangan yang mengatur tentang kinerja Komisi Pemberantasan Korupsi menjalankan tugas dan fugsinya untuk mencegah terjadinya tindak korupsi dan pola dan strategi Komisi Pemberantasan Korupsi dalam mencegah terjadinya tindak pidana korupsi.

\section{Analisis Data}

Metode Analisis data dilakukan dengan pola berpikir deskriptif yuridis normatif. Dalam penelitian ini hasil data yang diperoleh akan diolah dan dianalisis secara kualitatif (Soekanto, 1986).

\section{Hasil dan Pembahasan}

\section{Strategi Komisi Pemberantasan Korupsi Dalam Mencegah Terjadinya Korupsi melalui pendekatan Politik hukum, Penegakkan Hukum dan Budaya Hukum \\ Pendekatan Politik Hukum}

Strategi pendekatan politik hukum dalam upaya pencegahan tindak pidana korupsi menurut (Hamzah, 2017) pengertian formal politik hukum hanya mencakup satu tahap saja yaitu menuangkan kebijaksanaan pemerintah dalam bentuk produk hukum atau disebut "legislative drafting", sedangkan dalam pengertian materiil politik hukum mencakup legislative drafting, legal executing, dan legal review.

Dalam upaya pemberantasan korupsi produk hukum yang dibuat untuk mencegah dan memberantas korupsi dengan mengeluarkan Undang-Undang Nomor 28 Tahun 1999 tentang penyelenggaraan negara yang bersih dan bebas Korupsi Kolusi dan 
Studi Analisis Hukum Kewenangan dan Tugas Komisi Pemberantasan Korupsi dalam

Mencegah Tindak Pidana Korupsi Berdasarkan Ketentuan Undang-Undang Nomor 19

Tahun 2019

Nepotisme (KKN) dan UU No. 31 Tahun 1999 (diubah dengan UU No. 20 Tahun 2001) tentang Pemberantasan Tindak Pidana Korupsi.

Dengan demikian, prinsip negara hukum berarti menjunjung tinggi supremasi, persamaan kedudukan di hadapan hukum, serta menjadikan hukum sebagai landasan operasional dalam menjalankan sistem penyelenggaraan kehidupan bermasyarakat, berbangsa dan bernegara. Pada Pasal 15 ayat (1) Undang-Undang Nomor 10 Tahun 2004 tentang Pembentukan Peraturan Perundang-undangan menentukan bahwa: "Perencanaan penyusunan undang-undang dilakukan dalam suatu Prolegnas".

Penjelasan Pasal tersebut antara lain agar dalam pembentukan Peraturan Perundang-undangan dapat dilaksanakan secara berencana, maka pembentukan peraturan perundang-undangan perlu dilakukan berdasarkan Prolegnas. Prolegnas hanya memuat program penyusunan peraturan perundang-undangan tingkat pusat. Dalam penyusunan program tersebut perlu ditetapkan pokok materi yang hendak diatur serta kaitannya dengan peraturan perundangundangan lainnya. Oleh karena itu, prolegnas disusun secara terkoordinasi, terarah, dan terpadu yang disusun bersama oleh Dewan Perwakilan Rakyat dan Pemerintah, yang sebelumnya mengacu terlebih dulu pada RPJMN.

Lahirnya berbagai undang-undang yang mengatur pemberantasan terhadap tindak pidana korupsi dipengaruhi oleh kondisi politik saat masing-masing undangundang itu lahir. Sebagaimana yang telah diugkapkan bahwa politik sangat mempengaruhi lahirnya produk hukum.

Fungsi dan peran hukum sangat dipengaruhi dan kerapkali diintervensi oleh kekuatan politik. Sementara itu, untuk membangun tertib tata hukum dan meminimalisasikan pengaruh politik "judicial review" sebenarnya dapat dijadikan alat kontrol yang baik. Otonomi hukum di Indonesia cenderung lemah terutama jika berhadapan dengan subsistem politik, maka salah satu upaya strategi pencegahan pemberantasan korupsi di Indonesia faktanya sulit dilakukan.

Oleh karenanya dalam menempatkan posisi politik hukum untuk strategi pencegahan dan pemberantasan korupsi berarti melihat perilaku korupsi kejahatan yang luar biasa karena dampak negatif dan kerugian yang ditimbulkan sudah membahayakan kehidupan negara. Seperti kita ketahui Sistem politik yang dijalankan juga dapat mempengaruhi untuk dilakukannya pemberantasan korupsi.

Pencegahan dan Pemberantasan korupsi dari penataan sistem politik yang berkaitan dengan politik hukum, seperti kasus korupsi yang terjadi hingga saat ini masih ada beberapa kasus korupsi skala besar yang masih ditutupi maupun dilindungi agar tidak terkena hukuman hal ini karena dipengaruhi oleh politik dari penguasa yang sedang saat itu berkuasa. Korupsi merupakan kejahatan yang bersifat lintas negara, sehingga korupsi tidak hanya berdampak bagi masyarakat suatu negara namun juga bagi masyarakat global. Oleh karena itu, diperlukan kerja sama lintas negara agar pemberantasan korupsi dapat berjalan dengan maksimal.

Hal inilah yang kemudian mendorong dikeluarkannya United Nations Convention Against Corruption (UNCAC). UNCAC pada dasarnya merupakan 
Arief Rahman, Warto Utomo, Bangbang Panca Kusuma, Muhammad Thariq Almuqtadir

kesepakatan yang dibuat di antara negara-negara yang menjadi anggota PBB di dalam memberantas korupsi. Di Indonesia, UNCAC telah diratifikasi dalam Undang-Undang No 7 Tahun 2006 Tentang Pengesahan United Nations Convention Against Corruption, 2003

\section{Penegakkan Hukum}

Usaha untuk memberantas korupsi sudah menjadi masalah global bukan lagi nasional atau regional. Ada usaha terutama desakan rakyat agar korupsi diberantas habis sehingga jika perlu digunakan hukum darurat, seperti pidana yang berat, sistem pembalikan beban pembuktian, pembebasan, penanganan korupsi dari instansi pemerintah kepada suatu badan independen yang terjamin kredibilitasnya dan integritasnya. Upaya untuk dapat melaksanakan pemberantasan korupsi secara efektif dan efisien salah satunya adalah melalui penerapan Sistem Pembalikan Beban Pembuktian dan pembentukan suatu badan atau lembaga khusus yang independen dalam rangka pemberantasan tindak pidana korupsi yang disebut Komisi Pemberantasan Korupsi (KPK) (Ulang Mangun Sosiawan, Peran Komisi Pemberantasan Korupsi (KPK) Dalam Pencegahan Dan Pemberantasan Korupsi, Jurnal Penelitian Hukum DE JURE, Vol. 19 No. 4, Desember 2019, hlm 517-538).

Di Indonesia lembaga Khusus pemberantasan Tindak Pidana Korupsi telah dibentuk berdasarkan Undang-Undang No. 30 tahun 2002 sebagaimana diubah dengan Undang-Undang No. 19 Tahun 2019 tentang Komisi Pemberantasan Tindak Pidana Korupsi (KPK), yang menyatakan :

Komisi Pemberantasan Tindak Pidana Korupsi (KPK) adalah lembaga Negara yang dalam melaksanakan tugas dan wewenangnya bersifat independen dan bebas dari pengaruh kekuasaan manapun.

KPK dibentuk dengan tujuan meningkatkan daya guna dan hasil guna terhadap upaya pemberantasan tindak pidana korupsi. Dalam menjalankan tugas dan wewenangnya, KPK berasaskan pada, kepastian hukum, keterbukaan akuntabilitas, kepentingan umum, dan proporsionalitas.

Pencegahan dan penghalangan korupsi adalah konsep yang saling berhubungan. Jika pencegahan korupsi yang efektif telah ada, bekerja, dan diketahui dengan baik (well-kown) oleh pelakupelaku korupsi yang petensial, pencegahan korupsi tersebut dapat berfungsi sebagai penghambat yang kuat terhadap orang-orang yang berupaya untuk melaksanakan korupsi. Ketakutan untuk ditangkap merupakan instrument penghalang yang kuat.

Ada banyak strategi pencegahan yang lazim diterapkan dalam perusahaan/organisasi/lembaga-lembaga publik. Masing-masing strategi mempunyai kelebihan dan kekurangan. Salah satu strategi pencegahan yang dilakukan KPK adalah strategi penegakkan hukum, diantara:

a. Melakukan penyadapan dan mereka pembicaraan.

b. Memerintahkan seseorang pergi keluar negeri 
Studi Analisis Hukum Kewenangan dan Tugas Komisi Pemberantasan Korupsi dalam

Mencegah Tindak Pidana Korupsi Berdasarkan Ketentuan Undang-Undang Nomor 19

Tahun 2019

c. Meminta keterangan kepada bank atau lembaga keuangan lainnya tentang keadaan keuangan tersangka atau terdakwa yang sedang diperiksa.

d. Memerintahkan kepada bank atau lemabaga keuangan lainnya untuk memblokir rekening yang diduga hasil dari korupsi milik terdakwa atau tersangka atau pihak lain yang terkait.

e. Memerintahkan kepada pimpinan atau atasan tersangka untuk memberhentikan sementara tersangka dari jabatannya.

f. Meminta data kekayaan dan data perpajakan tersangka atau terdakwa kepada yang terkait.

g. Menghentikan sementara suatu transaksi keuangan, transaksi perdagangan, dan perjanjian lainnya atau pencabutan sementara perizinan, lisensi serta konsesi yang dilakukan atau dimiliki oleh tersangka atau terdakwa yang diduga berdasarkan bukti awal yang cukup ada hubungannya dengan tindak pidana korupsi yang sedang diperiksa.

h. Meminta bantuan Interpol Indonesia atau instansi penegak hukum negara lain untuk melakukan pencarian, penangkapan dan penyitaan barang bukti di luar negeri.

Meminta bantuan Kepolisian atau instansi lain yang terkait untuk melakukan penangkapan, penahanan, penggeledahan dan penyitaan dalam perkara tindak pidana korupsi yang sedang ditangani.

Di Indonesia, penegakkan hukum terkait korupsi telah menjadi prioritas utama dari pemerintah. Oleh karena itu, terkait dengan upaya tersebut KPK sangat dibutuhkan terhadap upaya-upaya pencegahan dan pemberantasan korupsi. Para pelaku yang terbukti bersalah harus dihukum berat sehingga menimbulkan efek jera, bukan sebaliknya diberikan hukuman yang ringan/minimal bahkan dibebaskan.

Putusan ringan/minimal dalam kasus korupsi masih ditemukan dalam putusan hakim. Misalnya pada satu kasus korupsi hukuman yang dijatuhkan berupa pidana penjara selama 4 (empat) tahun dan denda sebesar Rp. 200.000.000,- subsider 3 bulan kurungan adalah pidana minimal karena maksimalnya adalah 20 tahun, bahkan bisa seumur hidup apalagi pemidanaan tersebut disertai perintah agar terdakwa ditahan. Padahal, tuntutan jaksa adalah penjara selama 5 tahun dengan perintah supaya terdakwa ditahan dan denda sebesar Rp. 200.000.000,-subsider 6 bulan kurungan. Logikanya pemidanaannya harus berat. Hal ini membuktikan bahwa hakim kurang peka terhadap upaya-upaya pencegahan dan pemberantasan korupsi karena pidana yang dijatuhkan tidak akan memberikan efek jera.

Pada analisis yang lain, putusan-putusan hakim yang melemahkan upaya-upaya pencegahan maupun pemberantasan korupsi, secara tidak langsung juga tidak kondusif bagi upaya-upaya untuk meningkatkan penghormatan dan pemenuhan hak asasi manusia, khususnya di Indonesia.

Sedangkan menyangkut strategi penegakkan hukum tindak pidana korupsi dapat digunakan beberapa cara sebagaimana yang telah diatur dalam Undang-Undang Nomor 31 Tahun 1999 tentang Tindak Pidana Korupsi jo. UndangUndang Nomor 20 Tahun 
Arief Rahman, Warto Utomo, Bangbang Panca Kusuma, Muhammad Thariq Almuqtadir

2001, Undang-Undang Nomor 46 Tahun 2009 tentang Pengadilan Tindak Pidana Korupsi, Undang-Undang Nomor 7 Tahun 2006 tentang Ratifikasi Konvensi Anti Korupsi Tahun 2003. Ke-3 (tiga) undang-undang tersebut dapat digunakan, dimana salah satu undang-undang menyatakan bahwa seorang koruptor dapat diterapkan hukum mati.

Menurut Wakil Ketua KPK, menyatakan bahwa KPK akan menjadikan tuntutan tambahan, yaitu hukuman (pencabutan hak politik) sebagai standard untuk mencegah agar jangan sampai mantan pejabat publik, baik dari kalangan eksekutif, legislatif dan yudikatif, yang melakukan korupsi tidak dapat mengulangi penyalahgunaan jabatan barunya.

Berkaitan hal tersebut penulis berpendapat terkait strategi penegakkan hukum dalam upaya pencegahan korupsi bahwa pemerintah Indonesia sebaiknya memperbanyak perjanjian MLA dan ekstradisi guna mengefektifkan upaya pengembalian aset hasil tindak pidana. Kerjasama Ekonomi Asia Pasifik (APEC) yang berlangsung di Tiongkok tidak saja menyepakati hal-hal yang bersifat ekonomi, tetapi juga bersepakat membentuk wadah jejaring kerjasama antara lembaga otoritas anti korupsi dan lembaga penegakan hukum di kawasan yang dinamakan APEC Network of Anti Corruption Authorities And Law Enforcement Agencies (ACT- NET), untuk memberikan bantuan timbal balik, ekstradisi, kerjasama investigasi, dan kemudahan bagi setiap negara korban untuk dapat mengembalikan pelaku tindak pidana korupsi dan aset yang dilarikan di antara negara anggota APEC.

Secara hipotetis-teoretis, munculnya distansi persepsi-yaitu persepsi hukum dan persepsi publik terhadap Pengadilan Tindak Pidana Korupsi dapat terjadi baik karena adanya anomali hukum baik hukum pidana formil maupun materiil yang menjadi landasan bekerjanya Pengadilan Tindak Pidana Korupsi maupun karena kurangnya profesionalitas hakim yang dapat mewujud dalam ragam kualitas hakim seperti kurangnya kompetensi hakim maupun kurangnya integritas hakim (Sosiawan \& Indonesia, 2019).

Berkaitan dengan pemikiran di atas, menarik untuk dikemukakan pemikiran seorang tokoh reformis China yang hidup sekitar abad 11 yang mengemukakan (Jamin Ginting, APEC dan Antikorupsi, Kompas 19 November 2014, diakses pada tanggal 1 Juni 2021) :

ada dua unsur yang selalu muncul dalam pembicaraan masalah korupsi, yaitu hukum yang lemah dan manusia yang tidak benar.

Selanjutnya beliau mengatakan:

Tidak mungkin menciptakan aparat yang bersih hanya semata-mata mendasarkan rule of law sebagai kekuatan pengontrol (social control).

Selain itu beliau berkesimpulan :

Dalam memberantas korupsi penguasa yang punya moral tinggi dan hukum yang rasional serta efisien. 
Studi Analisis Hukum Kewenangan dan Tugas Komisi Pemberantasan Korupsi dalam Mencegah Tindak Pidana Korupsi Berdasarkan Ketentuan Undang-Undang Nomor 19

Tahun 2019

Bertolak dari pemikiran tersebut di atas, maka untuk merespon ekspektasi publik terhadap pencegahan tindak pidana korupsi, di satu sisi dan dalam upaya membangun KPK sebagai penegak hukum Tindak Pidana Korupsi yang berwibawa, di sisi lainnya, dibutuhkan evaluasi menyeluruh terhadap kinerja KPK itu sendiri.

\section{Budaya Hukum}

Aspek budaya hukum inilah yang mempunyai peranan yang sangat penting dalam penegakan hukum pidana di Indonesia. Menurut Lawrence M. Friedman menjelaskan mengenai konsep budaya hukum adalah sikap manusia terhadap hukum dan sistem hukumkepercayaan, nilai, pemikiran, serta harapannya (Dikutip dalam bukunya (lili, 2002).

Dengan kata lain budaya hukum adalah suasana pikiran sosial dan kekuatan sosial yang menentukan bagaimana hukum digunakan, dihindari atau disalah gunakan, tanpa adanya budaya/kultur hukum maka sistem hukum sendiri tak berdaya. Unsur budaya hukum ini mencakup opini-opini, kebiasaan-kebiasaan, cara berpikir, dan cara bertindak baik kepemimpinaan dalam hal ini presiden, pejabat penyelenggara Negara, pejabat aparatur Negara, maupun dari aparat penegak hukum harus memberi tauladan untuk tidak melanggar aturan hukum seperti melakukan tindak pidana korupsi, maka budaya hukum akan dapat membantu mengurangi tindak pidana korupsi. Hal ini dikarenakan budaya masyarakat Indonesia suka mengikuti atau meniru apa yang dilakukan pimpinannya. Tanpa budaya hukum maka sistem hukum akan kehilangan kekuatannya seperti yang di katakan Lawrence M. Friedman: "without legal culture, the legal system is meet-as dead fish lying in a basket, not a living fish swimming in its sea".

Gambaran mengenai budaya hukum dalam unsur-unsur sistem hukum adalah struktur hukum diibaratkan sebagai mesin yang menghasilkan sesuatu, substansi hukum diibaratkan produk yang di hasilkan oleh mesin, dan budaya hukum merupakan apa saja atau siapa saja yang memutuskan untuk menjalankan mesin serta membatasi penggunaan mesin.

Menurut Satjipto Rahardjo (Rahardjo, 2008) bahwa:

Dalam usaha untuk membenahi hukum di Indonesia kita perlu menaruh perhatian yang seksama terhadap masalah perilaku bangsa, kehidupan hukum tidak hanya menyangkut urusan hukum teknis, seperti pendidikan hukum tetapi menyangkut soal pendidikan dan pembinaan perilaku individu dan sosial yang luas.

Menurut (Warassih, Medan, \& Mahmutarom, 2005) bahwa:

Aspek perilaku (budaya hukum) aparat penegak hukum perlu dilakukan penataan ulang dari perilaku budaya hukum yang selama ini dilakukan oleh aparat penegak hukum sebelumnya karena seseorang menggunakan hukum atau tidak menggunakan hukum sangat tergantung pada kultur (budaya) hukumnya.

Telah terbukti bahwa akibat perilaku hukum aparat penegak hukum yang tidak baik, tidak resisten terhadap suap, konspirasi, dan KKN, menyebabkan banyak perkara tindak pidana korupsi yang tidak dapat dijerat oleh hukum. Korupsi sebagai kejahatan 
Arief Rahman, Warto Utomo, Bangbang Panca Kusuma, Muhammad Thariq Almuqtadir

terjadi, apabila dalam diri seseorang terdapat adanya niat, kemampuan, adanya peluang dan target yang sesuai dengan yang diinginkan. Kelemahan bangsa kita adalah mengenai mental /moral, budaya latah sering ikut-ikutan, kurang adanya kontrol terhadap diri sendiri, tidak mempunyai kesadaran terhadap hukum mana yang baik mana yang tidak baik misalnya dengan menyogok aparat penegak hukum.

Seperti dikemukakan (Rahardjo, 2008) bahwa :

Budaya hukum erat hubungannya dengan kesadaran hukum. Jika budaya hukum merujuk pada penilaian tentang hukum yag baik atau tidak baik (sehingga menentukan pilihan untuk digunakan atau tidak digunakan) oleh individu dan masyarakat, maka kesadaran hukum lebih merujuk pada kesadaran atau nilainilai yang diharapkan ada.

Menurut (ㅂartono, 1976) bahwa:

Kesadaran hukum merupakan abstarksi yang lebih rasional daripada perasaan hukum yang hidup di dalam masyarakat.

Apabila pelaku tindak pidana korupsi ternyata tidak juga diadili berarti ada dukungan dari aparat penegak hukum itu sendiri dengan menutup-nutupi kasus para koruptor dengan negosiasi materi atau juga karena ada kepentingan politis untuk suatu kekuasaan.

Untuk itu Aparat penegak hukum yang benar dalam menunaikan tugasnya dapat berperan dalam membangun dan menata kembali budaya hukum dalam penegakan hukum pidana di Indonesia sesuai sila ke 5 Pancasila yaitu Keadilan seluruh Rakyat Indonesia, tidak memandang kaya atau miskin, pejabat atau bukan. Hal ini tentunya harus dimulai dari pimpinannya itu sendiri yaitu Presiden dan para penegak hukum seperti Kapolri, Jaksa Agung, maupun dari Ketua KPK, mereka dituntut untuk mengambil peran melalui budaya kerja yang tidak melanggar aturan hukum dan mempunyai sikap mental yang baik dan jujur, tidak dipengaruhi oleh kepentingan pribadi untuk memperkaya diri sendiri sehingga keadilan sosial bagi seluruh rakyat Indonesia sebagaimana tercantum dalam Pancasila dan asas persamaan di bidang dapat terwujud dengan benar.

Dalam rangka menciptakan peran budaya hukum dari sisi aparat hukum maka perilaku pimpinan dan para aparat penegak hukum mencakup polisi, jaksa, hakim agar dapat mengembalikan kepercayaannya kepada masyarakat dan menjalankan tugasnya dengan profesional maka hukum harus dikembalikan kepada akar moralitas, kultural dan religius, dan mengembalikan rasa keadilan rakyat tanpa diskriminasi.

Meskipun saat ini banyak para pemimpin yang memiliki kekuasaan tertinggi pada penyelenggara negara bahkan pemimpin partai yang sebelumnya mendengungdengungkan anti korupsi, setelah menjabat di pemerintahan ternyata banyak yang melakukan tindak pidana korupsi bahkan dilakukan oleh para pejabat tinggi yang tidak diragukan ilmu pengetahuan agamanya, yang seharusnya mereka tahu mana yang benar mana yang salah malah sepertinya melakukan korupsi sudah dianggap biasa tanpa ada rasa malu dan tanpa merasa bersalah. Padahal kemajuan dan kesuksesan 
Studi Analisis Hukum Kewenangan dan Tugas Komisi Pemberantasan Korupsi dalam

Mencegah Tindak Pidana Korupsi Berdasarkan Ketentuan Undang-Undang Nomor 19

Tahun 2019

sebuah bangsa amat ditentukan seberapa kuat budaya malu memengaruhi perilaku masyarakatnya. Semakin maju dan beradab sebuah bangsa semakin kuat dan kokoh budaya malunya yang menjadi pijakan dalam kehidupan sehari-hari. Budaya malu tersebut secara jelas ditunjukkan negara-negara maju.

\section{Strategi Komisi Pemberantasan Korupsi Dalam Mencegah Terjadinya Korupsi Melalui Kerjasama}

Manusia adalah faktor terpenting dari tindakan korupsi. Selain sebagai makhluk individu, manusia juga merupakan makhluk sosial. Sebagai individu, manusia menampilkan diri pribadi yang memiliki cipta, rasa dan karsa. Sebagai makhluk sosial, manusia mempertahankan eksistensinya melalui proses interaksi dengan manusia lainnya dalam kehidupan bermasyarakat. Tidak akan pernah ada manusia yang benarbenar bisa hidup tanpa bantuan, tanpa berhubungan dengan manusia lain. Interkasi yang dimaksud adalah dengan menjalin kerjasama dengan para pihak melalui sosialisasi korupsi untuk tidak korupsi.

Berkaitan dengan hal tersebut diatas maka Strategi Komisi Pemberantasan Korupsi dalam mencegah Terjadinya Korupsi adalah sebagai berikut:

\section{Kerjasama Dengan Lembaga Lain (Luar Negeri)}

Di dalam perkembangan pemberantasan korupsi KPK meyakini bahwa tugas pemberantasan korupsi harus dijalankan melalui sinergi dengan berbagai pihak, baik di tingkat eksekutif, legislatif, maupun masyarakat di dalam dan luar negeri. Yang tidak boleh luput, lembaga antikorupsi dari negara lain juga harus dilibatkan dalam meningkatkan kerja sama dalam upaya pemberantasan korupsi. Upaya ini dilakukan mengingat bahwa korupsi tergolong kejahatan luar biasa (extra ordinary crime) yang bisa terjadi melintasi batas-batas suatu negara. Karenanya, penanganannya juga harus dilakukan secara luar biasa dan melibatkan banyak lembaga antikorupsi di berbagai negara. Darí praktek terbaik negara lain, kita belajar untuk memperbaiki diri. Begitu juga dengan lembaga lain yang melihat kinerja KPK cukup progresif dalam pemberantasan korupsi di Tanah Air karena mampu menangani kasus-kasus besar. Dari berbagai praktek terbaik itu, sejumlah negara tercatat pernah belajar dan meniru strategi KPK dalam upaya di bidang pencegahan maupun penindakan tindak pidana korupsi. Misalnya pada 2014, lembaga antkorupsi asal Timor Leste Comissao Anti-Corrupçao $(C A C)$, secara khusus datang dan belajar di KPK selama beberapa pecan.

KPK juga menjalin kerja sama dengan Anti-Corruption Commission (ACC) Bangladesh. Dalam waktu dekat, kerja sama ini akan dipererat melalui penandatanganan nota kesepahaman bersama $(\mathrm{MoU})$ yang meliputi pertukaran informasi dalam bidang pencegahan korupsi, berbagi informasi praktek terbaik dalam bidang pemberantasan korupsi, kerja sama dalam hal penyelenggaraan kegiatan pendidikan, pelatihan, dan penelitian, serta bertukar kepakaran dalam hal keorganisasian dan penegakan hukum untuk peningkatan kapasitas. Kemudian, kedua lembaga sepakat untuk meningkatkan hubungan kerja sama agar pemberantasan korupsi di kedua negara berjalan lebih efektif.

\section{Kerjasama Dengan BPK dan BPKP}


Arief Rahman, Warto Utomo, Bangbang Panca Kusuma, Muhammad Thariq Almuqtadir

Komisi Pemberantasan Korupsi (KPK) meningkatkan kerja sama di bidang pencegahan korupsi dengan dua instansi, yakni Badan Pengawasan Keuangan dan Pembangunan (BPKP) dan Badan Pemeriksa Keuangan (BPK). Dengan BPKP, KPK melanjutkan kerjasama di bidang Kordinasi dan Supervisi Pencegahan (Kor-supgah) korupsi.

Harapannya, upaya ini dapat mendorong terciptanya kualitas pelayanan publik yang lebih baik penganggaran yang berpihak pada kesejahteraan rakyat, pengadaan barang dan jasa yang efektif, efisien, dan transparan, adil, dan akuntabel, termasuk pengelolaan di bidang pendapatan.

Upaya pencegahan tindak pidana korupsi tidak hanya berdampak pada berkurangnya potensi kerugian negara, tetapi juga menjaga reputasi pemerintah Indonesia di mata dunia. Hal ini sangat penting karena terkait dengan reputational risk. Dasar dari kepercayaan masyarakat adalah tata kelola pemerintahan yang bersih.

\section{Kerjasama Dengan Kemendikbud}

Kementerian Pendidikan dan Kebudayaan (Kemendikbud) kembali menegaskan komitmen dalam pemberantasan praktik korupsi melalui pembaruan kerja sama dengan Komisi Pemberantasan Korupsi (KPK). Diharapkan dengan kerja sama ini dapat meningkatkan kemampuan Kemendikbud untuk memenuhi tanggung jawabnya, baik kepada Tuhan maupun kepada publik.

Kerja sama yang diprakarsai KPK ini meliputi pendidikan anti korupsi, pertukaran data dan/atau informasi, sistem pencegahan korupsi, serta pelayanan pengaduan masyarakat dan penertiban barang milik negara.

Kemendikbud telah memasukkan nilai-nilai karakter yang kuat dengan semangat anti korupsi ke dalam muatan mata pelajaran dalam kurikulum pendidikan. Menurut Mendikbud, pendidikan anti korupsi diperkenalkan kepada peserta didik sedini mungkin agar tertanam ke dalam jiwa peserta didik untuk membentuk karakter integritas yang kokoh.

Terkait sistem pencegahan korupsi, Kemendikbud dan KPK mendorong penguatan dalam mekanisme laporan harta kekayaan negara (LHKPN), dan penerapan wilayah bebas dari korupsi (WBK) serta wilayah birokrasi bersih dan melayani (WBBM). Tak hanya itu, pengendalian gratifikasi juga menjadi salah satu pokok penguatan dalam kerja sama Kemendikbud dengan lembaga antirasuah tersebut.

Upaya pengendalian gratifikasi ditempuh dengan mendirikan Unit Pengendalian Gratifikasi (UPG) yang memfasilitasi pelaporan penerimaan gratifikasi, melayani konsultasi terkait gratifikasi, dan berkoordinasi dengan KPK terkait penetapan status gratifikasi. Saat ini sistem pelaporan penyimpangan (whistle blowing system) di Kemendikbud dapat dilakukan di kanal Posko Pengaduan Inspektorat Jenderal.

\section{Kerjasama Dengan Perguruan Tinggi}

Peran lembaga pendidikan atau dunia universitas sangat strategis dalam upaya percepatan pemberantasan tindak pidana korupsi. Beberapa Fakultas Hukum di Indonesia telah melakukan kajian terkait tindak pidana korupsi maupun 
Studi Analisis Hukum Kewenangan dan Tugas Komisi Pemberantasan Korupsi dalam

Mencegah Tindak Pidana Korupsi Berdasarkan Ketentuan Undang-Undang Nomor 19

Tahun 2019

eksaminasi/bedah kasus terhadap putusan peradilan dan secara mandiri membangun Pusat Studi yang mengusung isu fokus anti Korupsi.

Selain itu, kerjasama KPK-Perguruan Tinggi dalam bidang pencegahan korupsi antara lain melalui pendidikan anti-korupsi/kurikulum anti-korupsi, penelitian, sosialisasi dan partner kampanye antikorupsi. Sedangkan dalam bidang penindakan, kerjasama dengan perguruan tinggi dalam hal pemberian keterangan ahli di persidangan dan narasumber dalam hal pelatihan Penyelidik/Penyidik/Penuntut Umum.

Berbagai kegiatan pencegahan korupsi juga secara aktif dilakukan oleh Perguruan Tinggi, misalnya kampanye, sosialisasi, pendidikan anti korupsi dan kegiatan lainnnya yang terus menerus menginisiasi, mendorong, meningkatkan gerakan anti korupsi yang lebih masif.

Perguruan Tinggi sebagai mitra strategis dalam pemberantasan korupsi juga melaksanakan kegiatan mengkonsolidasikan berbagai pihak yang memiliki kepedulian yang sama untuk bersama memerangi korupsi.

Berbagai fakta menunjukkan betapa signifikan kontribusi yang diberikan kampus dalam mengawal amanat reformasi selama ini. Dan dengan sumber daya manusia yang dimiliki, diyakini kampus tidak hanya mampu merumuskan problem korupsi yang menjadi masalah bangsa selama ini, namun juga mampu memberkan altematf solusi guna percepatan permberantasan beserta strategi intervensinya.

\section{Kerjasama Dengan PPATK}

KPK bersama Pusat Pelaporan Analisis dan Transaksi Keuangan (PPATK) menandatangani Memorandum of Understanding (MoU) tentang pencegahan dan pemberantasan tindak pidana pencucian uang.

Ketua PPATK mengatakan, penandatanganan ini dilakukan untuk meningkatkan kerjasama dengan KPK. Terlebih, KPK sudah termasuk lembaga yang mempunyai wewenang untuk menyelidiki dan menyidik kasus tindak pidana pencucian uang (money laundering).

Ketua KPK menjelaskan, bahwa dalam MoU ditetapkan bahwa money laundering tak hanya dilakukan pihaknya dengan KPK saja. Ke depan akan dilakukan juga bersama Ditjen Pajak, Ditjen Bea Cukai dan Badan Narkotika Nasional (BNN). Otomatis, kerjasama mengenai tindak pidana pencucian uang meluas ke enam lembaga negara.

Sebelum UU tentang Tindak Pidana Pencucian Uang diubah, hanya ada dua institusi yang berhak menindaklanjuti temuan PPATK terkait tindak pidana pencucian uang, yaitu kepolisian dan Kejaksaan. Tapi, setelah UU diamandemen menjadi UU No. 8 Tahun 2010, salah satu mandatnya adalah memperluas lembaga negara yang bisa menindaklanjuti temuan PPATK.

\section{Kerjasama Dengan Otoritasi Jasa Keuangan}

Untuk memberantas korupsi dan memajukan negara Indonesia, para lembagalembaga negara bekerja sama membuat perencanaan usaha-usaha dan melaksanakan tindakan dari perencanaan tersebut secara bersama-sama. Lembaga-lembaga negara yang telah bekerja sama adalah OJK dan KPK dalam memberantas korupsi. Diharapkan dengan kerja sama antara OJK dan KPK semakin efektif dalam upaya mencegah dan 
Arief Rahman, Warto Utomo, Bangbang Panca Kusuma, Muhammad Thariq Almuqtadir

memberantas korupsi dalam bidang sektor jasa keuangan di Indonesia ini yang semakin berkembang dalam tindakan korupsi. Kerja sama antara OJK dan KPK tidak hanya pada pemerintahan saja tetapi juga untuk sektor lainnya.

OJK dan KPK adalah wujud dari antara kerja sama pelaksanaan tindakan pemerintah dalam Good Governance. OJK untuk industri jasa keuangan yang sudah menjadi salah satu lembaga keuangan di Indonesia. Dalam penerapan Good Governance di bidang industri jasa keuangan, OJK masih selalu terus dituntut untuk selalu meningkatkan kinerja dan kualitas dalam penerapan Good Governance menangani industri jasa keuangan. Karena jika keputusan-keputusan yang diambil kurang efektif bisa menimbulkan krisis keuangan seperti yang terjadi pada tahun 1998 dan 2008. Upaya yang dilakukan OJK dan KPK dalam kerja sama ini, yaitu :

a. Tetap melaksanaan tugas dan wewenangnya masing-masing

b. Pertukaran informasi dan data

c. Kerja sama dalam menetapkan program untuk pencegahan tindak pidana korupsi

d. Sebagai narasumber dalam pelaksanaan tugas masing masing

e. OJK dikhususkan ahli dalam menangani perkara kasus tindak pidana korupsi di sektor jasa keuangan

OJK juga khusus menangani lembaga keuangan maupun lembaga non keuangan sehingga peluang untuk korupsi di negara Indonesia dapat ditangani dengan cepat.

\section{Kerjasama Dengan Ormas Islam}

Salah satu ormas Islam terbesar di Indonesia Nahdatul Ulama (NU) mampu menempatkan diri dengan baik, tidak berpolitik praktis tapi paham keinginan rakyat dan peduli dengan rakyat Indonesia.

Pengurus Besar Nahdatul Ulama (PBNU), ini tidak hanya menjadi benteng terdepan melawan radikalisme dan intoleransi, tapi juga terdepan melawan korupsi.

Luar biasa NU, inilah yang selama ini diharapkan oleh rakyat Indonesia yang 85\% lebih adalah muslim. Menjadikan Islam sebagai yang terdepan dalam memberantas korupsi, mencerdaskan umat bukan memperalat umat untuk kepentingan politik praktis.

PBNU mengingatkan kepada seluruh pengurusnya untuk tidak menyalatkan jenazah koruptor. Hal ini sesuai hasil Musyawarah Nasional Alim Ulama di Cirebon pada 2013.

Pengurus NU dilarang menyalatkan jenazah koruptor. Ini bukti bahwa NU tidak hanya bergerak secara moral tapi sekaligus memberkan dukungan kepada KPK. Sekali lagi, ini bukan muncul tiba-tiba.

Selain keputusan dalam Munas Alim Ulama agar jenazah koruptor tak disalatkan, karena menilai korupsi memiliki daya rusak yang cukup besar. PBNU pun mendukung jika koruptor dihukum mati.

PBNU mampu mengindentifikasi dengan baik musuh utama negara ini. Selama ini NU telah berjuang mempertahankan NKRI, menangkal radikalisasi dan kini mereka turut akitf dalam pemberantasan korupsi. NU menilai bahwa negara sulit maju, rakyat tidak sejahtera karena korupsi. 
Studi Analisis Hukum Kewenangan dan Tugas Komisi Pemberantasan Korupsi dalam Mencegah Tindak Pidana Korupsi Berdasarkan Ketentuan Undang-Undang Nomor 19

Tahun 2019

Kalau korupsi memiliki daya rusak sedemikian rupa, termasuk juga memiliki implikasi yang luas atas penderitaan rakyat, maka pelakunya layak dihukum mati.

NU sudah tegas melawan korupsi. Sementara itu, Ketua KPK mendukung seruan PBNU soal pelarangan mensalatkan jenazah koruptor. Dia menilai dalam menguatkan karakter bangsa, pendidikan agama sangat penting untuk ditanamkan sejak dini.

Menurutnya, larangan yang dikeluarkan PBNU dalam mensalatkan jenazah koruptor bisa memberikan dampak luas dalam upaya pemberantasan korupsi di masyarakat.

Seperti diketahui, jajaran pengurus PBNU yang didampingi KH. Said Aqil Siradj bertemu dengan pimpinan KPK. Kedatangan mereka untuk memberikan dukungan pada KPK, di tengah upaya pelemahan lembaga antirasuah tersebut.

Untuk memperlihatkan keseriusan PBNU mendukung KPK, Ketua Umum PBNU saat mendatangi Komisi Pemberantasan Korupsi (KPK) untuk meperlihatkan dukungan kepada lembaga anti rasuah tersebut menegaskan, meski banyak pihak yang menyerang dan menganggap KPK tak dibutuhkan lagi, pihaknya menilai pemerintah masih membutuhkan KPK.

NU di belakang KPK. NU jihad melawan korupsi. NU akan selalu berpihak pada kebenaran untuk menegakan undang-undang dan hukum yang seadil-adilnya. Yang dinantikan oleh warga NU adalah jihad melawan korupsi, dan menjadikan Islam sebagai ujung tombak melawan korupsi.

\section{Kesimpulan}

1. Tidak dapat dipungkiri, bahwa anggapan bahwa wewenang KPK yang lebih menonjol di bidang penindakan dibanding pencegahan. Hal itu juga diakui oleh pihak KPK, salah satunya karena yang mencuat ke media lebih banyak upaya-upaya KPK di bidang penindakan. Media dan masyarakat lebih tertarik dengan kasus-kasus, apalagi kasus yang diawali operasi tangkap tangan. Namun, sebenarnya hal itu terjadi di periode awal, kedua, dan ketiga. Sebenarnya pencegahan sudah mulai dilakukan di sektor haji, minerba, bansos, hibah, dan pertanian. Di periode berikutnya, dipertegas kembali dengan mengembangkan konsep penindakan dan pencegahan yang berbasis pendekatan integratif. Upaya pencegahan tindak pidana korupsi tidak hanya berdampak pada berkurangnya potensi kerugian negara, tetapi juga menjaga reputasi pemerintah Indonesia di mata dunia. Hal ini sangat penting karena terkait dengan reputational risk. Dasar dari kepercayaan masyarakat adalah tata kelola pemerintahan yang bersih;

2. KPK dalam mencegah korupsi berdasarkan analisa hukum dialkukan melalui beberapa strategi yaitu Strategi Pendekatan politik hukum, penegakkan hukum dan budaya hukum serta bekerja sama dengan Kemendikbud. Kerja sama yang diprakarsai KPK ini meliputi pendidikan anti korupsi, pertukaran data dan/atau informasi sistem pencegahan korupsi, serta pelayanan pengaduan masyarakat dan penertiban barang milik negara. Kemendikbud telah memasukkan nilai-nilai karakter 
Arief Rahman, Warto Utomo, Bangbang Panca Kusuma, Muhammad Thariq Almuqtadir

yang kuat dengan semangat anti korupsi ke dalam muatan mata pelajaran dalam kurikulum pendidikan. Menurut Kemendikbud, pendidikan anti korupsi diperkenalkan kepada peserta didik sedini mungkin agar tertanam ke dalam jiwa peserta didik untuk membentuk karakter integritas yang kokoh. KPK juga menjalin kerja sama dengan Anti-Corruption Commission (ACC) Bangladesh. Dalam waktu dekat, kerja sama ini akan dipererat melalui penandatangan nota kesepahaman bersama $(\mathrm{MoU})$ yang meliputi pertukaran informasi dalam bidang pencegahan korupsi; berbagi informasi praktik terbaik dalam bidang pemberantasan korupsi, kerja sama dalam hal penyelenggaraan kegiatan pendidikan, pelatihan, dan penelitian, serta bertukar kepakaran dalam hal keorganisasian dan penegakan hukum untuk peningkatan kapasitas. 
Studi Analisis Hukum Kewenangan dan Tugas Komisi Pemberantasan Korupsi dalam Mencegah Tindak Pidana Korupsi Berdasarkan Ketentuan Undang-Undang Nomor 19

Tahun 2019

\section{Bibliografi}

Ali, Achmad. (2002). Keterpurukan hukum di Indonesia: penyebab dan solusinya. Ghalia Indonesia.

Djaja, Ermansjah. (2009). Memberantas Korupsi Bersama KPK Kajian Yuridis Normatif UU Nomor 31 Tahun 1999 juncto UU Nomor 20 Tahun 2001 Versi UU Nomor 30 Tahun 2002. Jakarta: Sinar Grafika.

Hamzah, Andi. (1991). Korupsi di Indonesia: masalah dan pemecahannya.

Hamzah, Andi. (2017). Hukum Pidana Indonesia. Sinar Grafika.

Hartono, C. F. G. (1976). Peranan kesadaran hukum masyarakat dalam pembaharuan hukum. Binacipta.

Jaya, Nyoman Serikat Putra, \& Serikat, Nyoman. (2008). Bahan Kuliah Sistem Peradilan Pidana (Criminal Justice System). Magister Ilmu Hukum, Semarang, Indonesia.

Lilik, Mulyadi. (2007). Hukum Acara Pidana Normatif, Teoritis, Praktik dan Permasalahannya. Bandung: PT Alumni.

Rahardjo, Satjipto. (2008). Membedah Hukum progresif, Jakarta: PT. Kompas Media Nusantara.

Soekanto, Soerjono. (1986). Pengantar Penelitian Hukum, Universitas Indonesia. The Legal Protection of Consumer Rights in Sale-Purchase through E-Commerce.

Sosiawan, Ulang Mangun, \& Indonesia, HAMR. (2019). Peran Komisi Pemberantasan Korupsi (KPK) dalam pencegahan dan pemberantasan korupsi. Jurnal Penelitian Hukum De Jure, 19(4), 517-538.

Suyatno, Korupsi. (2005). Kolusi dan Nepotisme. Pustaka Sinar Harapan, Jakarta.

Warassih, Esmi, Medan, Karolus Kopong, \& Mahmutarom. (2005). Pranata Hukum: sebuah telaah sosiologis. Suryandaru Utama. 